\title{
Training for Manufactured Construction (TRAMCON) - Benefits and Challenges for Workforce Development at Manufactured Housing Industry
}

\author{
Mohamad AHMADZADE RAZKENARI ${ }^{1}$, Andriel Evandro FENNER ${ }^{1}$, Hamed HAKIM ${ }^{1}$, and
} Charles J. KIBERT ${ }^{2}$

${ }^{1}$ PhD student, Rinker School of Construction Management, University of Florida

2 Professor, Rinker School of Construction Management, University of Florida

*Corresponding author's e-mail:mahmadzade@ufl.edu

\begin{abstract}
Manufactured Housing (MH) is the process of producing building units or entire buildings in an offsite factory and transporting them to the site for installation and assembly. The application of advanced manufacturing technologies into the housing process not only will increase productivity, but also can provide a safer work environment, stable work location, long-term growth opportunities, and career progression for employees. Today, the $\mathrm{MH}$ workforce is facing problems with worker quality and retention. The rising demand for $\mathrm{MH}$ indicates the need for training a multi-skilled labor force for this industry. This paper evaluates the essence of an educational program for $\mathrm{MH}$ industry and discusses the rationale for training the $\mathrm{MH}$ workforce in comparison to conventional training programs. In response to the stated problem of Inadequate training programs, the curriculum for Training Manufactured Construction (TRAMCON) was developed by the University of Florida and delivered throughout Florida by the TRAMCON Consortium. While the quantitative results in labor performance improvement in the factory plants have not yet been established, the major strengths and challenges of the program are discussed.
\end{abstract}

\section{KEYWORDS}

Modular homes; construction workforce training; manufactured housing, multi-skilled workforce

\section{INTRODUCTION}

In the construction industry, workforce training has always played a significant role in improving the efficiency and productivity of the industry. The TRAMCON program was developed to improve the skills of the workforce in the prefabrication industry, focusing on manufactured housing factories. No similar program previously existed for the manufactured construction industry. The TRAMCON program aims to increase the role of prefabrication in the construction industry and address the lack of multi-skilled workers by developing a training program that embraces construction techniques and the specialized skills required in the manufacturing plants. 
TRAMCON is a four-level training program that is comprised of modules that total about 250 contact hours per level. The TRAMCON study units range from 30 to 230 hours and include eight industry recognized certificates. The U.S. Department of Labor funded the program and the University of Florida developed the educational materials. The University of Wisconsin-Stout developed some of the supplementary training materials for the program. The TRAMCON Consortium consists of the University of Florida and four state college partners: Miami-Dade College, Santa Fe College, Polk State College, and Seminole State College, who deliver the program throughout Florida. The purpose is to implement and test the program in Florida and then, with industry support and collaboration, migrate it to other states with extensive prefabrication activities.

\section{Manufactured Housing}

In the U.S., manufactured housing industry is one of the primary providers of affordable housing. Modular homes are now becoming attractive to a broader market by offering far more options in terms of size, style, and budget. Manufactured and modular homes are expected to be safer, more cost-effective and sustainable than conventional approaches because of the factory-controlled environment and rapid assembly process (McGuinness and Bennett 2006). The U.S. Census Bureau, American Housing Survey (2016) shows that the proportion of manufactured homes to new-built single-family homes has decreased since 2000 (Figure 1). However, Manufactured Housing Institute report for year 2016 shows that manufactured homes accounted for $14 \%$ of all new single-family homes sold in the U.S. and their shipment has increased by $15 \%$. Figure 2 shows the total number of shipped homes in the U.S. for each year from 1959 to 2016 based on Manufactured Housing Institute data.

The manufactured housing industry is expected to continue expanding in the long term. Industry value added (IVA) is estimated to rise an annualized 3.3\% over the ten years to 2022 which is higher than the average US GDP growth in the same period which is $2.0 \%$ (O'Halloran 2017). However, O'Halloran discusses that IVA is high due to heavy losses incurred during the 2008 U.S. recession. After the recession, many companies declared bankruptcy and sold their businesses to the larger operators. Thus, overall, the industry is declining, and customers are losing their interest in manufactured homes. One of the primary reasons could be the limited amount of technological change in the industry (Kibert et. al. 2016). The product quality has not improved significantly even with the increased level of customization and energy-efficient strategies introduced to stimulate demand.

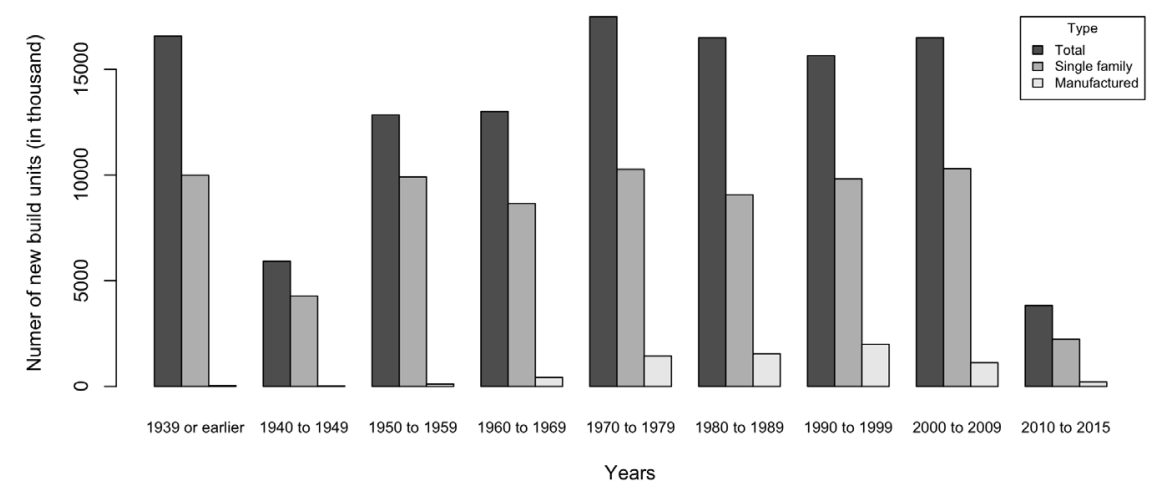

Figure 1. Proportion of manufactured housing to total new built houses 


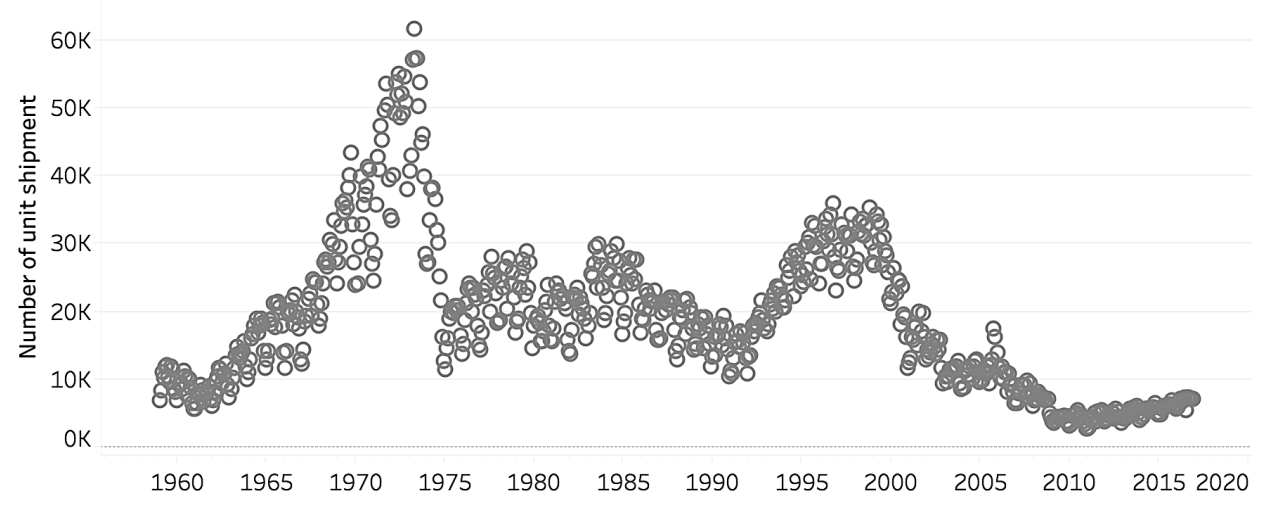

Figure 2. Manufactured housing trend

\section{Construction workforce}

Labor productivity and management is a key factor in the assessment of construction project performance (Kisi et al. 2016). A significant portion of the total construction project cost is expended on labor (Karimi et al. 2017a). In fact, the labor productivity in construction is an indeterminate factor and hard to estimate (Allmon et al. 2000). Furthermore, recruiting and retaining of skilled workers has been a persistent challenge for the North American construction industry over the past decades (Ho 2016). The Construction Industry Institute (1992) predicted a shortage of skilled workers in the U.S. throughout the 1990s. Several construction firms have reported difficulties due to the skilled labor shortage (Karimi et al. 2017a). The work slowdown in the construction industry during the 2008 recession resulted in a temporary reform of the workforce shortage (Taylor et al. 2016). However, the current economic recovery period has already brought back craft shortages in some regions (Taylor et al. 2016).

The nature of the construction industry often discourages people from joining the workforce (Agapiou et al. 1995). Construction careers are generally perceived to be low-status jobs with low career advancement opportunities (Ho 2016). Construction tasks are thought to require less skill and have higher safety hazards compared to other industries (Al-Bayati et al. 2016). Following the individual's interests and perceptions, other factors that influence career choice are wages, the educational system, location, and required skills. The construction workforce is experiencing significant challenges arising from the increasing use of prefabrication in construction processes. Prefabrication processes generally need multi-skilled workers with comprehensive knowledge of traditional construction and manufacturing crafts in both on-site and off-site locations (Goulding et al. 2012). Adopting prefabricated building methods in manufactured housing industry entails a particular set of training and experience. The training programs in factories are usually more effective than those for site-built construction. However, an extensive amount of knowledge and technology must be transferred throughout the whole manufacturing process (McGuinness and Bennett 2006).

\section{TRAINING IN THE CONSTRUCTION INDUSTRY}

The quality of training of the workforce for the construction industry has a major role in improving the efficiency, productivity, and quality of work. It can also increase the employability of the 
workers and keep them employed for longer durations (CITB 2003). In the U.S., the National Center for Construction Education \& Research (NCCER) is a leading corporation in providing training programs and certifications in the construction industry. The Manufacturing Skill Standard Council (MSSC) is another organization that develops training programs and certifications for manufacturing production workers. The TRAMCON curriculum is a fusion of NCCER, MSSC, and manufactured construction specific training that will contribute to developing a flexible, multi-skilled workforce that applies construction skills in a factory setting.

\section{National center for Construction Education and Research (NCCER)}

The NCCER is a non-profit 501(c)(3) education foundation created in 1996 by several experts in the construction industry. The group created a standardized training program that evolved into a curriculum for more than 70 craft areas. The NCCER efforts to enhance construction workforce include accreditation, instructor certification, standardized curriculum, registry, assessment, certification. The NCCER Construction Core Curriculum is a prerequisite for all the crafts modules and must be completed before further crafts training. The Construction Core Curriculum modules cover topics such as basic safety, construction drawings, applied math for construction, an overview of hand and power tools, and basic communication skills. As part of TRAMCON, a Manufactured Construction Technology curriculum was developed to develop the construction side of the prefabricated and manufactured industry. Its purpose is to develop multi-skilled workers with knowledge of carpentry, plumbing, electrical, and HVAC systems.

\section{Manufacturing Skill Standard Council (MSSC)}

The MSSC is a non-profit 501(c)(3) industry-led system that aims to provide training, assessment, and certification of front-line production and material handling workers. The MSSC was the first U.S. system for manufacturing and logistics accredited under the ISO 17024 standard, which specifies criteria for the certification body and sets requirements for development and maintenance of certification. The MSSC offers a Certified Production Technician (CPT) and the Certified Logistics Technician (CLT) program. The CPT certification is addressed for higher skilled workers in all sectors of manufacturing. The curriculum modules include safety, quality practices and measurement, manufacturing processes and production, maintenance awareness, and green production. Certifications are awarded for each module as well as a full CPT certification at the end of the program. The CLT addresses technical competencies for workers in all supply chain facilities. A foundation-level CLT and a mid-level CLT certification are awarded in this program. Credit-hours of the CPT and CLT programs can also be transferred to some colleges and universities, with up to 12 hours for the full CPT and 4 hours for the full CLT.

\section{TRAINING FOR MANUFACTURED CONSTRUCTION (TRAMCON)}

Currently, the prefabrication and manufactured housing industry does not have a training program for its workforce, resulting in issues of worker quality and retention. The construction workforce needs to acquire construction skills covered in the NCCER program along with the production skills addressed in the MSSC. However, manufactured construction industry-specific skills are still lacking.

The TRAMCON program was developed to fulfill the demand of the growing demant for a welltrained labor force. The curriculum provides four different levels of certificates: Foundation, 
Basic, Advanced, and Supervisory. The trainees have an excellent opportunity to advance their knowledge and skills during the four levels of the program, and they can earn certificates by passing the tests designed for this purpose. For each level, the TRAMCON team at the University of Florida selected and implemented modules from NCCER, modules from MSSC, and newly developed supplementary materials. Students earn industry certifications from both the construction (NCCER) and manufacturing (MSSC) sectors. The full set of TRAMCON levels and certificates are shown in Table 1.

Table 1. A summary of the TRAMCON program including the four levels of training and the certifications that can be earned during each level

\begin{tabular}{|c|c|c|c|}
\hline Training unit & Contact hours & Curriculum & Industry certificate obtained \\
\hline \multicolumn{4}{|l|}{ Level 1 - Foundation } \\
\hline Intro to $\mathrm{MC}^{*}$ & 27.5 & TRAMCON & $\mathrm{N} / \mathrm{A}$ \\
\hline Construction Core & 72.5 & NCCER & $\begin{array}{l}\text { NCCER Wallet Card; OSHA 10- } \\
\text { Hour Card }\end{array}$ \\
\hline Manufacturing Core & 120 & MSSC & $\begin{array}{l}\text { MSSC Certified Production } \\
\text { Technician }\end{array}$ \\
\hline Total & 220 & & \\
\hline \multicolumn{4}{|l|}{ Level 2 - Basic } \\
\hline MC Technology 1 & 222.5 & NCCER & $\begin{array}{l}\text { NCCER Manufactured } \\
\text { Construction Level } 1\end{array}$ \\
\hline Basics of MC & 27.5 & TRAMCON & $\mathrm{N} / \mathrm{A}$ \\
\hline Total & 250 & & \\
\hline \multicolumn{4}{|l|}{ Level 3** - Advanced } \\
\hline $\mathrm{MC}-\mathrm{Technology} 2$ & 232.5 & NCCER & $\begin{array}{l}\text { NCCER Manufactured } \\
\text { Construction Level } 2\end{array}$ \\
\hline Advanced Topics in MC & 27.5 & TRAMCON & $\mathrm{N} / \mathrm{A}$ \\
\hline Total & 260 & & \\
\hline \multicolumn{4}{|l|}{ Level 4** - Supervisor } \\
\hline Project Supervision & 85 & NCCER & NCCER Project Supervision \\
\hline 30 Hours safety training & 30 & OSHA & $\begin{array}{l}\text { OSHA } 30 \text {-Hour Construction } \\
\text { Industry card }\end{array}$ \\
\hline $\begin{array}{l}\text { Sustainable } \\
\text { Manufacturing }\end{array}$ & 20 & TRAMCON & $\mathrm{N} / \mathrm{A}$ \\
\hline Future Topics in MC & 30 & TRAMCON & $\mathrm{N} / \mathrm{A}$ \\
\hline Field Installation Guide & 20 & TRAMCON & $\mathrm{N} / \mathrm{A}$ \\
\hline Total & 185 & & \\
\hline
\end{tabular}

* $\mathrm{MC} \equiv$ Manufactured Construction

** Level 3 and 4 also require three months on-the-job training

\section{Manufactured Construction - Foundation}

The Foundation Level consists of three main training segments, starting with the "Introduction to Manufactured Construction". This curriculum provides information about the nature of the manufactured construction industry, the production environment, and the construction process for manufactured houses. The second segment is the NCCER "Construction Core" curriculum that 
covers topics such as basic safety, communication skills, construction drawings, basic math, materials handling, hand tools, power tools, and employability skills. The third component is the manufacturing production core curriculum that is aligned with the MSSC CPT body of knowledge. The trainee can earn a 10-hour OSHA Construction Industry Outreach card and the NCCER Wallet Card upon successful completion of the "NCCER Core" and the CPT certificate upon completion of the manufacturing core.

\section{Manufactured Construction - Basic}

The purpose of the Basic Level is to provide trainees with a fundamental knowledge of carpentry, electrical, and plumbing skills. It consists of two main training segments. The first segment is "Manufactured Construction Technologist 1" that includes modules from the NCCER curriculum for carpentry, plumbing, and electricity Level 1 . The trainees learn about building materials, hand and power tools, and building framing and envelope systems in the carpentry modules. The plumbing modules introduce trainees to plastic piping and fittings, plumbing fixtures, and water distribution systems. The primary purpose of the electricity modules is introducing the National Electrical Code requirements for residential wiring, device boxes, conductors and cables, residential electrical services, and electrical test equipment. The trainees can earn the NCCER Manufactured Construction Level 1 certification upon successful completion of this curriculum. The second unit of basic level is the "Basics of Manufactured Construction" curriculum. It covers the detailed construction process, delivery, and assembly of manufacturing homes. It also clarifies the importance of quality control process and procedures for detection of defects.

\section{Manufactured Construction - Advanced}

The intention of Advanced Level training is to provide additional knowledge in carpentry, electrical, and plumbing, in addition to several modules in Heating, Ventilation, and Air conditioning (HVAC) systems. The MC Basic certificate holders should complete a minimum of three months on-the-job training in a manufactured housing plant prior to starting the advanced training program. The advanced level consists of two main training segments. The first part is the "Manufactured Construction Technologist 2" that includes the NCCER curriculum for carpentry, plumbing, and electricity Level 2 as well as modules from NCCER curriculum for HVAC Level 1. The trainee can earn the NCCER Manufactured Construction Level 2 certification after passing the required written and performance tests. The second segment is the "Advanced topics in Manufactured Construction". It centers on the building standards and applicable codes, the energy code, the code enforcement process, and systems testing. It reviews the condition of other prefabrication industries, such as panelized buildings, structural insulated panels, precast concrete buildings, modular prefabricated steel buildings, and truss manufacturing.

\section{Manufactured Construction - Supervisor}

The Supervisor Level targets workers who seek to be promoted as supervisors. The trainees should complete at least three months on-the-job training after obtaining the MC Advanced Certificate to start this level of the program. The supervisor level consists of five training modules. The NCCER Project Supervision certification is the first part of the curriculum. It is a comprehensive program that gives essential skills to the trainees to improve their performance as leaders. Upon successful completion of the NCCER Project Supervisor curriculum and passing the required written and performance tests the trainee will obtain the NCCER Project Supervision certification. The next part is OSHA 30 Hours safety training program that includes fundamental safety concepts and 
individual topics like personal protective equipment (PPE), work zone safety, and fire protection and prevention. Upon successful completion of the safety training, the trainee will obtain the OSHA 30-hour card. The next two segments focus on the contemporary issue in manufactured construction. The third segment is "Sustainable Manufacturing" that presents design and construction strategies for manufactured construction. The supervisor trainees learn about sustainable construction, green building concepts, and green building rating systems. The fourth part is called "Future Topics in Manufactured Construction". Although there are clearly many possible issues that will impact the industry in future, there are three topics that are most likely to be prime areas of change: lean construction, automation, and information technologies. Lean construction is about the efficiency of the manufacturing process, eliminating waste, and speeding production. Besides, it is very likely that the industry will have to adopt advanced technologies in the logistics system and manufacturing process. An introduction to advanced technologies is covered in this segment, for example, computer-controlled machine tools, 3D printers, laser cutters, and robotics, all connected to the computer-aided design and manufacturing (CAD/CAM) systems and Building Information Modeling (BIM) design software. The last part of the supervisor level is "Field Installation Guide" that addresses the key practices and considerations for site assembly and installation of utilities for manufactured homes and modular homes.

\section{DISCUSSION AND CONCLUSION}

The program officially started on Fall 2015 in four different Florida state colleges including Miami-Dade College, Santa Fe College, Polk State College, and Seminole State College. All colleges recorded data on their registered students, their grades, achieved certificates, and level of study. In this paper we will provide the data from Santa Fe College. Based on this data, 21 students registered in Fall 2015 for the foundation level of the program. From these students, 5 dropped during the semester, while the rest could finish the level and get the relevant certificates. From these 16 remaining students, 12 advanced to second level in the Spring 2016 semester, one continued in the Summer 2016 semester, and the other three did not register for the next level.

In the Spring of 2016, 37 new students registered for the foundation level. This number went to 55 for Summer 2016, 35 for Fall 2017, and 35 Spring 2017. In total, 185 students registered for the foundation level at Santa Fe College. Of these, 81 of them successfully completed the course and 50 dropped the course. From all the student who finished the Foundation level, 69 registered for the Basic level, 44 completed the course successfully, and 5 dropped the course.

The program has a strong motivation for training basic skills for working in construction and manufacturing. Two advantages of the certification are that, (1) by mapping the certifications into the curriculum, participants can be fast-tracked into the program through demonstration of competency by presentation of the appropriate certification; (2) participants can use their training to earn college credit for AS degree programs through Florida. Through the Gold Standard Career Pathways articulation process, students will be able to articulate credits for college degrees such as in Engineering Technology, Construction Management, and Construction technology.

The number of students who dropped the program is still high. A major reason is perceived to be that students with some experience and training for lower level jobs decide to leave the program to follow job opportunities. The growing construction market could be another reason. Most of 
these participants were hired for jobs in the construction industry instead of manufactured construction. This could compromise the major goal of the program which was training skilled workers for manufactured housing plants. However, it should be noted that there is no manufactured housing plant near to Santa Fe College.

Finally, the program is intended to satisfy needs for skilled workers in manufactured construction plants in Florida. There is a tremendous potential to implement the program in other states with a significant manufactured housing industry, such as Texas, Pennsylvania, and California. However, there are many continuing challenges to implementing the program in Florida and further study is needed to monitor the implementation process and results to improve the program prior to wide deployment.

\section{REFERENCES}

Agapiou, A., Price*, A. D., McCaffer, R. (1995). "Planning Future Construction Skill Requirements: Understanding Labor Resource Issues." Constr. Manage. Econ., 13(2), 149-161. Al-Bayati, A. J., Abudayyeh, O., Fredericks, T., Butt, S. E. (2016). "Reducing Fatality Rates of the Hispanic Workforce in the US Construction Industry: Challenges and Strategies." J. Constr. Eng. Manage., 143(3), 04016105.

Allmon, E., Haas, C. T., Borcherding, J. D., Goodrum, P. M. (2000). "US Construction Labor Productivity Trends, 1970-1998." J. Constr. Eng. Manage., 126(2), 97-104.

CITB. (2003). "Construction industry training board." < http://www.citb.co.uk/> (July, 2017).

Goulding, J., Nadim, W., Petridis, P., Alshawi, M. (2012). "Construction Industry Offsite Production: A Virtual Reality Interactive Training Environment Prototype." Advanced Engineering Informatics\}, 26$\}$ (1\}), 116\}.

Ho, P. H. (2016). "Labor and Skill Shortages in Hong Kong's Construction Industry." Engineering, Construction and Architectural Management, 23(4), 533-550.

Karimi, H., Taylor, T. R., Goodrum, P. M. (2017a). "Analysis of the Impact of Craft Labor Availability on North American Construction Project Productivity and Schedule Performance." Constr. Manage. Econ., 35(6), 368-380.

Kibert, C. J., Chini, A. R., Rumpf-Monadizadeh, S., Razkenari, M. A., Fenner, A. E., Hakim, H., and Garg, Y. (2016). Advanced Topics in Manufactured Construction. University of Florida, United States.

Kisi, K. P., Mani, N., Rojas, E. M., Foster, E. T. (2016). "Optimal Productivity in Labor-Intensive Construction Operations: Pilot Study." J. Constr. Eng. Manage., 143(3), 04016107.

Manufactured housing institute. (2016). <http://www.manufacturedhousing.org/> (July, 2017).

McGuinness, S., and Bennett, J. (2006). "Examining the Link between Skill Shortages, Training Composition and Productivity Levels in the Construction Industry: Evidence from Northern Ireland." The International Journal of Human Resource Management, 17(2), 265-279.

O'Halloran, K. (2017). "Prefabricated home manufacturing in the US;" $<$ http://clients1.ibisworld.com/reports/us/industry/default.aspx?entid=397> (July, 2017).

Taylor, T., Karimi, H., Goodrum, P. M., Albattah, M. (2016). "Is there a Demographic Craft Labor Cliff that Will Affect Project Performance." Construction Industry Institute, the University of Texas-Austin.

U.S. Census Bureau. (2016). <https://www.census.gov/> (July, 2017).

U.S. Bureau of Labor Statistics. (2016). <https://www.bls.gov/> (July, 2017). 